\title{
Stabilization of Iron-Based Fuel Cell Catalysts by Non-Catalytic Platinum
}

\author{
Anna K. Mechler, $\oplus^{1, a, z}$ Nastaran Ranjbar Sahraie, ${ }^{1}$ Vanessa Armel, ${ }^{1}$ Andrea Zitolo, ${ }^{2}$ \\ Moulay Tahar Sougrati, ${ }^{1}$ Jan N. Schwämmlein, $\mathbb{1}^{3}$ Deborah J. Jones, ${ }^{1, *}$ \\ and Frédéric Jaouen $(\mathbb{1}), * *, \mathrm{z}$ \\ ${ }^{1}$ Institut Charles Gerhardt de Montpellier, CNRS - Université de Montpellier - ENSCM, 34095 Montpellier, Cedex 5 , \\ France \\ ${ }^{2}$ Synchrotron SOLEIL, L'orme des Merisiers, 91192 Gif-sur-Yvette, France \\ ${ }^{3}$ Technical Electrochemistry, TU Munich, 85748 Garching, Germany
}

\begin{abstract}
Since a few years, non-precious metal catalysts with iron or cobalt as active centers show sufficient activity to be viable candidates as electrocatalysts for the oxygen reduction reaction (ORR) in polymer electrolyte membrane fuel cells (PEMFC). They can sustain substantial current densities when operated at low potentials. However, their stabilization at high cathode potentials, necessary for high energy efficiency, remains a daunting task. Here an Fe-N-C catalyst is stabilized over the whole potential range through functionalization with minute amounts of platinum. With the addition of 1 to $2 \mathrm{wt} \% \mathrm{Pt}$, the present $\mathrm{Pt} / \mathrm{Fe}-\mathrm{N}-\mathrm{C}$ hybrid catalysts show a similar current density at $0.8 \mathrm{~V}$ than Fe-N-C but are much more stable during operation in PEMFC. Various characterization techniques, including CO stripping, demonstrate that platinum in these hybrid catalysts is ORR-inactive, not only initially but also after the PEMFC potentiostatic test. It is proposed that the present platinum species protects the Fe-based active sites from the ORR by-product $\mathrm{H}_{2} \mathrm{O}_{2}$, or reactive oxygen species produced from its reaction with surface Fe. This proof-of-concept paves the way for a new class of hybrid catalysts, where the activity and stability of Me-N-C catalysts can be independently addressed.

(C) The Author(s) 2018. Published by ECS. This is an open access article distributed under the terms of the Creative Commons Attribution Non-Commercial No Derivatives 4.0 License (CC BY-NC-ND, http://creativecommons.org/licenses/by-nc-nd/4.0/), which permits non-commercial reuse, distribution, and reproduction in any medium, provided the original work is not changed in any way and is properly cited. For permission for commercial reuse, please email: oa@electrochem.org. [DOI: 10.1149/2.0721813jes]
\end{abstract}

(cc) BY-NC-ND

Manuscript submitted April 6, 2018; revised manuscript received August 20, 2018. Published September 29, 2018.

Metal-nitrogen-carbon materials comprising iron or cobalt (Me-N-C) have demonstrated high beginning-of-life activity for the oxygen reduction reaction (ORR), challenging platinum- based catalysts in polymer electrolyte membrane fuel cells (PEMFCs). ${ }^{1-3}$ However, they persistently show decaying electrochemical properties during operation. ${ }^{4,5}$ While some studies have reported a steady current density during operation in PEMFC at low electrochemical potential, where the cathode is limited by kinetics and mass-transport, final polarization curves have recurrently revealed a lowered ORR activity of Me-N-C catalysts. ${ }^{2}$ Therefore, the poor stability of non-precious metal catalysts in PEMFC operation is a major issue impeding their industrial application. The underlying degradation or deactivation mechanisms are still unclear. Proposed mechanisms include corrosion of the active sites themselves or of the surrounding carbon structure, ${ }^{6-9}$ or lowered utilization of active sites by (micro)pore flooding. ${ }^{4}$ Another explanation is based on the modification of Me-N-C catalysts by $\mathrm{H}_{2} \mathrm{O}_{2}$, produced in operando as an ORR by-product. This degradation mechanism has been proven ex situ with controlled amounts of peroxide. ${ }^{7,10}$ While Me-N-C catalysts have low activity toward $\mathrm{H}_{2} \mathrm{O}_{2}$ electroreduction, metallic platinum is an excellent catalyst. ${ }^{11-13}$ The prospect of improving the in operando stability of Me-N-C catalysts through functionalization with minute amounts of platinum is appealing. In previous studies on $\mathrm{Pt} / \mathrm{Me}-\mathrm{N}-\mathrm{C}$ hybrid catalysts however, the major part of their ORR activity stemmed from metallic platinum, impeding the evaluation of the hypothetical stabilization of $\mathrm{Fe}(\mathrm{Co})$ based active sites by platinum. ${ }^{14-18}$ In contrast to previous studies, the present $\mathrm{Pt} / \mathrm{Fe}-\mathrm{N}-\mathrm{C}$ hybrid materials comprise partially oxidized platinum that is ORR-inactive, as will be shown later. This allowed us to assess the effect of such particles on the stability of $\mathrm{Pt} / \mathrm{Fe}-\mathrm{N}-\mathrm{C}$ cathodes during PEMFC operation.

\footnotetext{
*Electrochemical Society Fellow.

**Electrochemical Society Member.

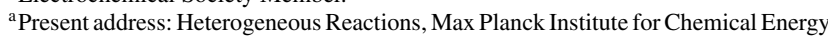

Conversion, 45470 Mülheim a.d. Ruhr, Germany.

zE-mail: anna.mechler@cec.mpg.de; frederic.jaouen@umontpellier.fr
}

\section{Experimental}

Synthesis of the catalysts.- $-\mathrm{Fe}_{1.0} \mathrm{~d}$ was synthesized via a dry ballmilling approach from a $\mathrm{Zn}$ (II) zeolitic imidazolate framework $\left(\mathrm{ZnN}_{4} \mathrm{C}_{8} \mathrm{H}_{12}\right.$, Basolite Z1200 from BASF, labelled ZIF-8), Fe(II) acetate (FeAc), and 1,10-phenanthroline (phen). $800 \mathrm{mg}$ of ZIF-8, $200 \mathrm{mg}$ of phen, and $31.5 \mathrm{mg}$ of FeAc were weighted and the dry powders were poured into $\mathrm{a} \mathrm{ZrO}_{2}$ crucible. Consequently, the catalyst precursor contained $1 \mathrm{wt} \%$ of metal and the mass ratio of phenanthroline to ZIF- 8 was $20 / 80$. Then, $100 \mathrm{ZrO}_{2}$ balls of $5 \mathrm{~mm}$ diameter were added and the crucible was sealed in air and placed in a planetary ball-miller (FRITSCH Pulverisette 7 Premium) to undergo 4 cycles of $30 \mathrm{~min}$ of ballmilling at $400 \mathrm{rpm}$. The resulting catalyst precursor was pyrolyzed at $1050^{\circ} \mathrm{C}$ in $\mathrm{Ar}$ for $1 \mathrm{~h}$.

For functionalization of $\mathrm{Fe}_{1.0} \mathrm{~d}$ by $\mathrm{Pt}$ nanoparticles, $300 \mathrm{mg}$ of $\mathrm{Fe}_{1.0} \mathrm{~d}$ was impregnated with a Pt-salt $\left(\mathrm{Pt}\left(\mathrm{NH}_{3}\right)_{4} \mathrm{Cl}_{2} \cdot \mathrm{H}_{2} \mathrm{O}, 99 \%\right.$, Interchim) dissolved in $\mathrm{H}_{2} \mathrm{O}$. For all hybrid catalysts, a fixed aliquot of 550 $\mu \mathrm{L}$ was dropped stepwise in $100 \mu \mathrm{L}$ steps onto the catalyst powder, while the mixture was ground in between the additions. The sample has a slightly muddy character after the impregnation, showing the complete filling of the pores of $\mathrm{Fe}_{1.0} \mathrm{~d}$. In order to reach the targeted Pt-concentrations $(0.5,1.0$, or $2.0 \mathrm{wt} \%)$, the concentration of the $\mathrm{Pt}$ salt solution was adjusted (i.e. $19.7 \mathrm{mg} / \mathrm{mL}$ for $2 \mathrm{wt} \%, 9.9 \mathrm{mg} / \mathrm{mL}$ for $1 \mathrm{wt} \%$, and $4.9 \mathrm{mg} / \mathrm{mL}$ for $0.5 \mathrm{wt} \%$ ). The impregnated sample was then dried for $2 \mathrm{~h}$ in an oven at $80^{\circ} \mathrm{C}$ under air. The dry powder was introduced into a tube furnace with a quartz boat, and heated under $\mathrm{N}_{2}$ atmosphere from $300^{\circ} \mathrm{C}$ to $560^{\circ} \mathrm{C}$ at a rate of $4^{\circ} \mathrm{C} \cdot \mathrm{min}^{-1}$. The gas was then switched from $\mathrm{N}_{2}$ to $5 \% \mathrm{H}_{2} / \mathrm{N}_{2}$ atmosphere for $2 \mathrm{~h}$ at $560^{\circ} \mathrm{C}$. After the dwell time, the tube was removed from the oven and cooled down naturally under $\mathrm{N}_{2}$ atmosphere. The three hybrid catalysts are labeled $\mathrm{Pt}_{\mathrm{x}} \mathrm{Fe}_{1.0} \mathrm{~d}$, with $\mathrm{x}=0.5,1.0$ or $2.0 \mathrm{wt} \% \mathrm{Pt}$, corresponding to the theoretical calculated values of the Pt content in the final catalyst. This can be expected to be the maximal possible Pt content, due to losses by hydration of the Pt salt or during the preparation. In a control sample with nominally $2 \mathrm{wt} \% \mathrm{Pt}$ a final Pt content of $1.7 \pm 0.2 \mathrm{wt} \% \mathrm{Pt}$ was found with ICP-MS, i.e. the real Pt content can be estimated to be about $15 \%$ lower than the theoretical value. For comparison, a sample without the Pt impregnation step but with the subsequent thermal treatment in $5 \% \mathrm{H}_{2} / \mathrm{N}_{2}$ was prepared and is labelled $\mathrm{H}_{2}-\mathrm{Fe}_{1.0} \mathrm{~d}$. 
Physical characterization.- $\mathrm{N}_{2}$ sorption characterization was performed with automatic volumetric adsorption equipment (Micromeritics, Tristar). The samples were degassed at $100^{\circ} \mathrm{C}$ under vacuum for at least $8 \mathrm{~h}$ prior to the measurement in order to remove any guest molecules and/or adsorbed moisture. The total specific surface area was determined by the multipoint Brunauer-Emmett-Teller (BET) method. The scanning electron microscope was Hitachi S-4800 (Hitachi, Tokyo, Japan). The images were recorded after gold metallization of the sample. The utilized transmission electron microscope was a JEOL 2200FS with a $200 \mathrm{kV}$ field-emission electron gun. The maximum point resolution is $0.23 \mathrm{~nm}$ utilizing a CCD Gatan USC $4090 \times 4092 \mathrm{px}^{2}$ detector. The integrated energy-dispersive X-ray spectroscopy (EDS) has an energy resolution of $129 \mathrm{eV}$.

$\mathrm{X}$-ray absorption spectra at the $\mathrm{Pt}_{3}$-edge were recorded at room temperature at SAMBA beamline (Synchrotron SOLEIL). The beamline is equipped with a sagittal focusing Si 220 monochromator and two Pd-coated mirrors that were used to remove X-rays harmonics. Either catalyst powders or non-hot-pressed cathodes, prepared as described in the fuel cell Methods section, were examined. The latter were characterized before and after the fuel cell stability test. The spectra were recorded in fluorescence mode. A reference metallic Pt-foil (Goodfellow, PT000210, 99.95\%) was used for energy calibration.

${ }^{57} \mathrm{Fe}$ Mössbauer spectra were measured with a ${ }^{57} \mathrm{Co}: \mathrm{Rh}$ source. The experiments were conducted at room temperature. The spectrometer was operated with a triangular velocity waveform, and a $\mathrm{NaI}$ scintillation detector was used for the detection of the $\gamma$ rays. Velocity calibration was performed with a Fe-foil. The spectra were fitted individually with appropriate combinations of Lorentzian lines.

X-ray photoelectron spectroscopy (XPS) was performed with an ESCALAB 250, ThermoElectron. The source was a monochromatic $\mathrm{Al} \mathrm{K}_{\alpha}$ source $(1486.6 \mathrm{eV})$ with an energy resolution of $0.3 \mathrm{eV}$. The measurement spot had a size of $400 \mu \mathrm{m}$. All spectra were calibrated with the $\mathrm{C}_{1 \mathrm{~s}}$ energy of the $\mathrm{C}-\mathrm{C}$ bond at $284.8 \mathrm{eV}$. The spectra were fitted using Casa XPS software.

Rotating disc electrode measurements.-A Pine MSR Electrode Rotator was utilized with a RDE/RRDE precision shaft and glassy carbon tips. For $\mathrm{Fe}_{1.0} \mathrm{~d}$ and all $\mathrm{H}_{2}$-treated catalysts, an ink with $10 \mathrm{mg}$ catalyst, $108.4 \mu \mathrm{L}$ Nafion solution (5 wt\%, Sigma Aldrich), $300 \mu \mathrm{L}$ ethanol (99\%, API France), and $36.5 \mu \mathrm{L}$ ultrapure water (>18 M $\Omega$, Elga Classic DI system) was prepared. The ink was ultrasonicated for at least $30 \mathrm{~min}$. Finally, $7 \mu \mathrm{L}$ of this ink were deposited onto a glassy carbon disk with a diameter of $5 \mathrm{~mm}$ leading to a catalyst loading of $800 \mu \mathrm{g} \mathrm{cm}^{-2}$. As a reference, $4 \mathrm{mg}$ of a $5 \mathrm{wt} \% \mathrm{Pt} / \mathrm{C}$ catalyst, supplied by Johnson Matthey, was mixed with $6 \mathrm{mg}$ of $\mathrm{Fe}_{1.0} \mathrm{~d}$, consequently comprising the same amount of $\mathrm{Pt}$ as $\mathrm{Pt}_{2.0} \mathrm{Fe}_{1.0} \mathrm{~d}$, but $40 \%$ less Fe-based active sites. The ink and catalyst layer were prepared as described above, therefore resulting in a similar layer thickness. The prepared tips are then immersed into $0.1 \mathrm{M} \mathrm{HClO}_{4}$ (prepared from $70 \% \mathrm{HClO}_{4}$, Merck, and ultrapure water) in a glass cell with graphite as counter electrode, and a platinum wire in a separate compartment, saturated with $\mathrm{H}_{2}$, as a reversible hydrogen electrode (RHE). The potentiostat utilized was a VersaStat 3, Princeton Applied Research. The rotation rate was set to $1600 \mathrm{rpm}$ for all measurements. 20 cyclic voltammogramms (CVs) between 0.05 and $1.1 \mathrm{~V}_{\mathrm{RHE}}$ were applied for cleaning. Subsequently, CVs were recorded with $10 \mathrm{mV} \mathrm{s}^{-1}$ in $\mathrm{N}_{2}$ or $\mathrm{O}_{2}$ saturated electrolyte between 0.2 and $1.0 \mathrm{~V}_{\mathrm{RHE}}$, and the curves recorded in $\mathrm{N}_{2}$ were subtracted from the ORR curves to correct for non-faradaic and adsorption/desorption processes on the surface. Additionally, the iR-resistance of $20 \Omega$ was compensated during the measurement. For the Pt/C benchmark catalyst (46 wt\% Pt, Tanaka), $1.4 \mathrm{mg}$ were dispersed in $3 \mathrm{~mL}$ ultrapure water by ultrasonic treatment, and $20 \mu \mathrm{L}$ were deposited onto the glassy carbon tip and dried in air. This leads to a loading of $20 \mu \mathrm{g}_{\mathrm{Pt}} \mathrm{cm}^{-2}$. After cleaning cycles, the ORR polarization curve was recorded with $50 \mathrm{mV} \mathrm{s}^{-1}$ scan between 0.05 and $1.1 \mathrm{~V}_{\mathrm{RHE}}$. For all Fe-based catalysts the negative-going sweep is shown, while for $\mathrm{Pt} / \mathrm{C}$ the positive-going sweep was selected to avoid influences by Pt-oxide formation.

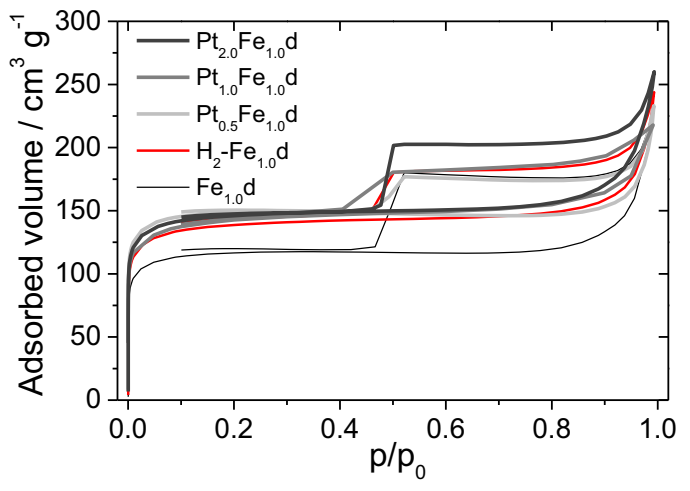

Figure 1. $\mathrm{N}_{2}$ sorption isotherms on $\mathrm{Fe}_{1.0} \mathrm{~d}, \mathrm{H}_{2}-\mathrm{Fe}_{1.0} \mathrm{~d}$, and the three hybrid catalysts.

Fuel cell measurements.-The utilized fuel cell test bench was built in-house. The single-cell fuel cell had graphite serpentine flow fields (Fuel Cell Technologies Inc.) and for the measurements a Biologic potentiostat with a 50 A load and EC-Lab software was used. The membrane electrode assemblies were pressed between the flow fields with a torque of $10 \mathrm{Nm}$ under a compression of $25 \%$, with Teflon-masks as separators. The fuel cell temperature was set to $80^{\circ} \mathrm{C}$ and the humidifiers were set to $85^{\circ} \mathrm{C}$ to obtain $100 \%$ relative humidity. The inlet pressures of both $\mathrm{H}_{2}$ (anode) and $\mathrm{O}_{2}$ (cathode) were set to 1 bar gauge. The flow rates were adjusted to approximately $50 \mathrm{sccm}$ downstream of the fuel cell. Polarization curves were recorded with $0.5 \mathrm{mV} \mathrm{s}^{-1}$, starting at $0.9 \mathrm{~V}$ and down to $0.3 \mathrm{~V}$, then back up. In the Figures, only the positive-going scan is shown. To test the stability, a constant voltage of $0.5 \mathrm{~V}$ was applied for $50 \mathrm{~h}$ under $\mathrm{H}_{2} / \mathrm{O}_{2}$ flows. For preparation of the cathode, $20 \mathrm{mg}$ of catalyst were dispersed in $652 \mu \mathrm{L}$ Nafion solution ( $5 \mathrm{wt} \%$ Nafion solution, density of 0.874 ), $326 \mu \mathrm{L}$ ethanol and $272 \mu \mathrm{L}$ ultrapure water and ultrasonicated for $1 \mathrm{~h}$. The ink was then deposited in three steps onto a $4.84 \mathrm{~cm}^{2}$ gas diffusion layer (GDL, Sigracet S10-BC) for a total catalyst loading of $4 \mathrm{mg} \mathrm{cm}^{-2}$. The cathode was dried in a vacuum oven at $80^{\circ} \mathrm{C}$ for $2 \mathrm{~h}$. The resulting ratio of dry Nafion ionomer to catalyst is 1.42 . As the anode the same GDL but pre-loaded with $0.5 \mathrm{mg}_{\mathrm{Pt}} \mathrm{cm}^{-2}$ was used. The electrodes were hot-pressed onto a Nafion NRE-211 membrane at $130^{\circ} \mathrm{C}$ for $2 \mathrm{~min}$. For post mortem analysis of the cathodes, for those experiments only the anode and membrane were hot-pressed. In situ CO-stripping was performed at the Technical University of Munich in another fuel cell test station (Fuel Cell Technology Hardware, Gamry potentiostat with load bank, software by Greenlight). The same MEAs as described before were utilized. For the $\mathrm{CO}$-stripping procedure, the cell temperature was decreased to $40^{\circ} \mathrm{C}$. $\mathrm{CO}$ was flowed through the system $(50 \mathrm{sccm})$ for $5 \mathrm{~min}$ at a constant potential of $0.06 \mathrm{~V}$ in order to adsorb $\mathrm{CO}$ molecules on any present metallic Pt species in the catalyst material. Subsequently, the system was purged again with $\mathrm{N}_{2}$ to avoid $\mathrm{CO}$ oxidation from the gas phase. During the $\mathrm{N}_{2}$ purge of $25 \mathrm{~min}$ the potential remained constant at $0.06 \mathrm{~V}$. In the subsequent cyclic voltammogram under nitrogen flow $(5 \mathrm{sccm})$ with $50 \mathrm{mV} \mathrm{s}^{-1}$ in the potential window between 0.05 and $1.1 \mathrm{~V}_{\mathrm{RHE}}$, adsorbed COmolecules on a Pt surface are oxidized during the anodic (positive) sweep. In a subsequent scan, no further $\mathrm{CO}$ oxidation can be expected and this is labelled as the blank measurement.

\section{Results}

Morphology and structural characterization of the catalysts.The porous structure in the hybrid $\mathrm{Pt} / \mathrm{FeNC}$ materials and $\mathrm{H}_{2} \mathrm{Fe}_{1.0} \mathrm{~d}$ was analyzed with $\mathrm{N}_{2}$ sorption and compared to that of $\mathrm{Fe}_{1.0} \mathrm{~d}$. All isotherms indicate a type IV porous structure, characterized by a major fraction of micropores along with small mesopores (Figure 1). The higher volume adsorbed at already $\mathrm{P} / \mathrm{P}_{0}=0.2$ for the hybrid $\mathrm{Pt} / \mathrm{FeNC}$ materials and also for $\mathrm{H}_{2}-\mathrm{Fe}_{1.0}$ d relative to $\mathrm{Fe}_{1.0} \mathrm{~d}$ reveals increased microporous area, mostly accounting for their higher specific surface 
Table I. Fitted parameters and relative absorption areas of spectral components derived from the analysis of the Mössbauer spectra shown in Figure 3. The errors for the relative absorption areas are $\pm 5 \%$ for the doublets and $\gamma$-Fe, and $\pm 1 \%$ for $\alpha$-Fe.

Relative Absorption Area (\%)

\begin{tabular}{|c|c|c|c|c|}
\hline \multirow[b]{2}{*}{ Spectral component $\downarrow$} & \multirow[b]{2}{*}{ Catalyst $\rightarrow$} & \\
\hline & & $\mathrm{Fe}_{1.0} \mathrm{~d}$ & $\mathrm{H}_{2}-\mathrm{Fe}_{1.0} \mathrm{~d}$ & $\mathrm{Pt}_{1.0} \mathrm{Fe}_{1.0} \mathrm{~d}$ \\
\hline & $\alpha-\mathrm{Fe}$ & 6 & 10 & 13 \\
\hline & $\gamma-\mathrm{Fe}$ & 5 & 5 & 9 \\
\hline & D1 & 54 & 56 & 46 \\
\hline & D2 & 35 & 29 & 32 \\
\hline & & \multicolumn{3}{|c|}{ Isomer shift $\left(\mathrm{mm} \mathrm{s}^{-1}\right)$} \\
\hline \multirow[t]{6}{*}{ Spectral component $\downarrow$} & Catalyst $\rightarrow$ & $\mathrm{Fe}_{1.0} \mathrm{~d}$ & $\mathrm{H}_{2}-\mathrm{Fe}_{1.0} \mathrm{~d}$ & $\mathrm{Pt}_{1.0} \mathrm{Fe}_{1.0} \mathrm{~d}$ \\
\hline & $\alpha-\mathrm{Fe}$ & $0.05(*)$ & $0.03+-0.01$ & $0.05+-0.01$ \\
\hline & $\gamma-\mathrm{Fe}$ & $-0.05\left(^{*}\right)$ & $-0.05\left(^{*}\right)$ & $-0.05+-0.03$ \\
\hline & D1 & $0.41+-0.01$ & $0.40+-0.01$ & $0.40+-0.02$ \\
\hline & D2 & $0.48+-0.06$ & $0.50+-0.03$ & $0.44+-0.03$ \\
\hline & & & upole splitting ( & \\
\hline \multirow[t]{3}{*}{ Spectral component $\downarrow$} & Catalyst $\rightarrow$ & $\mathrm{Fe}_{1.0} \mathrm{~d}$ & $\mathrm{H}_{2}-\mathrm{Fe}_{1.0} \mathrm{~d}$ & $\mathrm{Pt}_{1.0} \mathrm{Fe}_{1.0} \mathrm{~d}$ \\
\hline & D1 & $0.88+-0.02$ & $0.93+-0.01$ & $0.97+-0.03$ \\
\hline & D2 & $2.09+-0.32$ & $2.43+-0.14$ & $2.62+-0.13$ \\
\hline
\end{tabular}

area (Table S1). These changes are assigned to the thermal treatment in $5 \% \mathrm{H}_{2}$, forming new pores in the substrate used, namely $\mathrm{Fe}_{1.0} \mathrm{~d}$. The morphology of $\mathrm{Pt}_{1.0} \mathrm{Fe}_{1.0} \mathrm{~d}$ was then investigated, since, as will be seen later, $1.0 \mathrm{wt} \% \mathrm{Pt}$ was the lowest Pt amount for which stabilization of $\mathrm{Fe}_{1.0} \mathrm{~d}$ was observed in this work. A representative scanning electron microscopy (SEM) micrograph is shown in Figure 2, revealing porous particles of ca $200 \mathrm{~nm}$ assigned to the N-C support that results from the pyrolysis of ZIF-8. The inset shows a SEM micrograph recorded at higher magnification, revealing Pt particles with most frequent diameter of ca $8-10 \mathrm{~nm}$, even if a few larger Pt particles can also be seen in the lower magnification image as bright spots. TEM images reveal additionally some smaller Pt particles $(2-3 \mathrm{~nm})$ while EDX analysis proves that particles of both sizes contain Pt (Figure S1). The iron speciation in $\mathrm{Fe}_{1.0} \mathrm{~d}, \mathrm{H}_{2} \mathrm{Fe}_{1.0} \mathrm{~d}$ and $\mathrm{Pt}_{1.0} \mathrm{Fe}_{1.0} \mathrm{~d}$ was then investigated with ${ }^{57} \mathrm{Fe}$ Mössbauer spectroscopy (Figure 3). The analysis of the spectra reveals a sextet and a singlet assigned to $\alpha-\mathrm{Fe}$ and $\gamma-\mathrm{Fe}$, respectively, and two quadrupole doublets D1 and D2 (Table I). The latter are assigned to $\mathrm{FeN}_{\mathrm{x}} \mathrm{C}_{\mathrm{y}}$ moieties in low and medium spin states, the most active sites in Fe-N-C materials. ${ }^{19,20}$ The slightly higher contents of $\alpha$-Fe and $\gamma$-Fe in the $\mathrm{H}_{2}$-treated samples $\left(\mathrm{H}_{2} \mathrm{Fe}_{1.0} \mathrm{~d}\right.$ and all hybrid catalysts, Table I) can be explained on the basis of the partial etching of carbon by $\mathrm{H}_{2}$ during the thermal treatment in $5 \% \mathrm{H}_{2}$. This leads to the formation of novel or longer micropores, but also to the transformation of a small fraction of $\mathrm{FeN}_{4} \mathrm{C}_{\mathrm{y}}$ moieties into metallic iron. ${ }^{21}$ Since the parameters for D1 and D2 did however not change significantly by neither the $\mathrm{H}_{2}$ treatment or combined $\mathrm{Pt}$ deposition and $\mathrm{H}_{2}$ treatment, we conclude that the coordination of the $\mathrm{FeN}_{4} \mathrm{C}_{\mathrm{y}}$ moieties in $\mathrm{Pt}_{1.0} \mathrm{Fe}_{1.0} \mathrm{~d}$ is the same than that in $\mathrm{Fe}_{1.0} \mathrm{~d}$ or $\mathrm{H}_{2} \mathrm{Fe}_{1.0} \mathrm{~d}$.

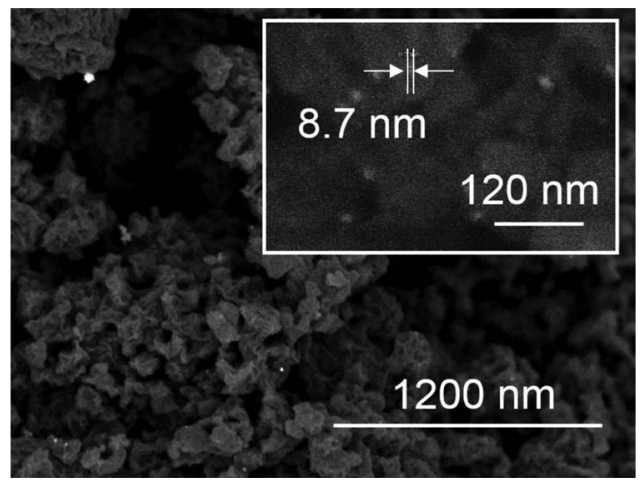

Figure 2. SEM in two magnifications of the hybrid catalyst $\mathrm{Pt}_{1.0} \mathrm{Fe}_{1.0} \mathrm{~d}$.
To investigate the platinum oxidation state, the catalysts were further analyzed by X-ray photoelectron spectroscopy (XPS) and X-ray absorption near-edge structure spectroscopy (XANES). The XPS Pt $\mathrm{Pt}_{4 \mathrm{f}}$ narrow scans for $\mathrm{Pt}_{0.5} \mathrm{Fe}_{1.0} \mathrm{~d}, \mathrm{Pt}_{1.0} \mathrm{Fe}_{1.0} \mathrm{~d}$ and $\mathrm{Pt}_{2.0} \mathrm{Fe}_{1.0} \mathrm{~d}$ are shown in Figure 4. In all three hybrid catalysts, more than $50 \%$ of the platinum atoms detected by XPS are oxidized $\left(\mathrm{Pt}^{2+}\right.$ and $\left.\mathrm{Pt}^{4+}\right)$, and the fraction of oxidized platinum increases with decreasing platinum content. ${ }^{22-24}$

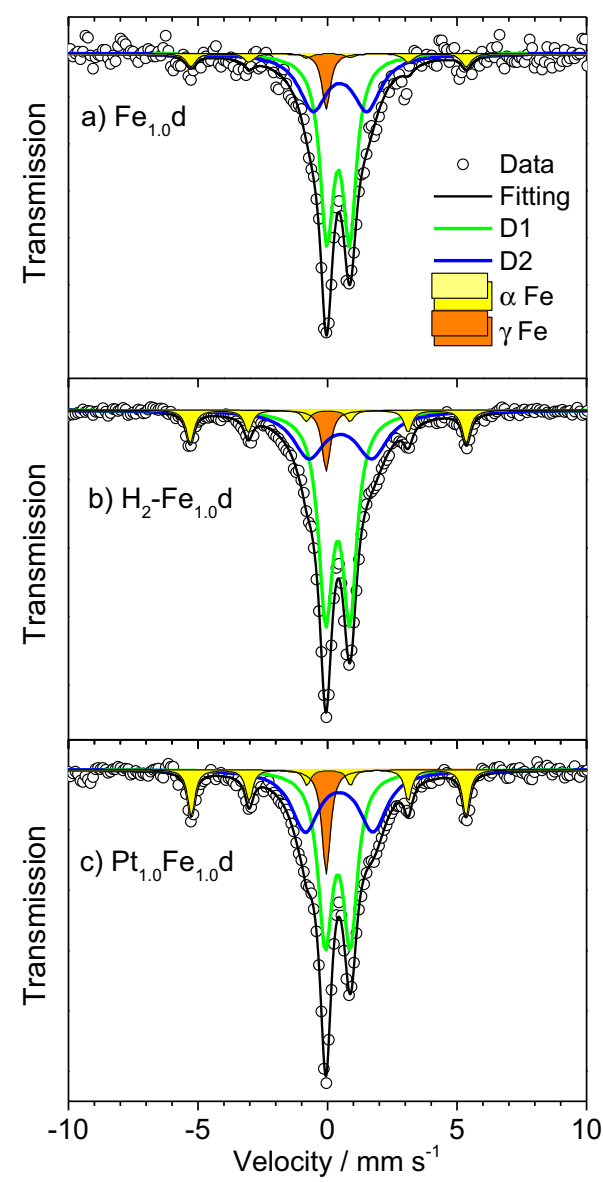

Figure 3. ${ }^{57} \mathrm{Fe}$ Mössbauer spectra measured at room temperature of a) $\mathrm{Fe}_{1.0} \mathrm{~d}$, b) $\mathrm{H}_{2}-\mathrm{Fe}_{1.0} \mathrm{~d}$ and c) $\mathrm{Pt}_{1.0} \mathrm{Fe}_{1.0} \mathrm{~d}$. 

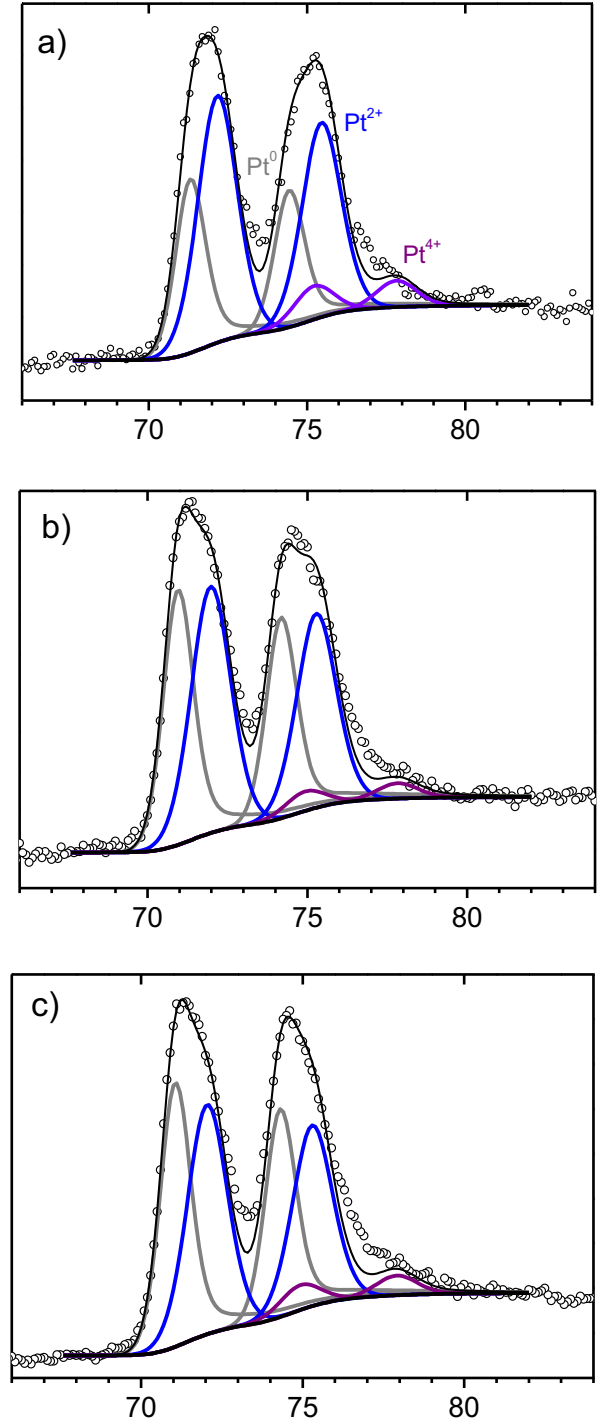

Figure 4. XPS $\mathrm{Pt}_{4 \mathrm{f}}$ narrow-scan spectrum of a) $\mathrm{Pt}_{0.5} \mathrm{Fe}_{1.0} \mathrm{~d}$, b) $\mathrm{Pt}_{1.0} \mathrm{Fe}_{1.0} \mathrm{~d}$ and c) $\mathrm{Pt}_{2.0} \mathrm{Fe}_{1.0} \mathrm{~d}$.

In comparison to other reports on the Pt oxidation state in Pt nanoparticles supported on different supports, the fraction of oxidized Pt in the present $\mathrm{Pt}_{\mathrm{x}} \mathrm{Fe}_{1.0} \mathrm{~d}$ hybrid catalysts seems higher than could be expected from the Pt particle size (Table S2). ${ }^{18,22,24,25}$ This suggests that the oxidation of the present Pt particles must affect more than the surface monolayer. This trend is confirmed by XANES, which shows a shift of the $\mathrm{Pt} \mathrm{L}_{3}$ absorption edge to higher energy with decreasing platinum content (Figure 5). Also, the white line intensity, correlated with the average oxidation degree, is more intense in the spectra of the hybrid materials relative to the reference Pt foil. ${ }^{26}$ However, it needs to be pointed out that this does not necessarily indicate a Pt-oxide. $\mathrm{Pt}$ can also be oxidized in other chemical compounds, as for example in Pt-nitrides. ${ }^{27,28}$

ORR and $\mathrm{H}_{2} \mathrm{O}_{2}$ reduction activity measurements.-The ORR activity was first determined with rotating disc electrode (RDE) measurements. The activity of $\mathrm{Fe}_{1.0} \mathrm{~d}$ (thin solid black curve in Figure 6a) is comparable to that previously reported. ${ }^{29}$ The baseline $\mathrm{H}_{2} \mathrm{Fe}_{1.0} \mathrm{~d}$ material (red curve in Figure 6a) shows a circa three-fold higher activity than $\mathrm{Fe}_{1.0} \mathrm{~d}$, which is assigned to its higher microporous area (Figure 1 and Table S1). Surprisingly, the three hybrid materials show an ORR-activity very similar to that of $\mathrm{H}_{2} \mathrm{Fe}_{1.0} \mathrm{~d}$ (Figure 6a, gray curves), indicating that platinum in these catalysts has no significant

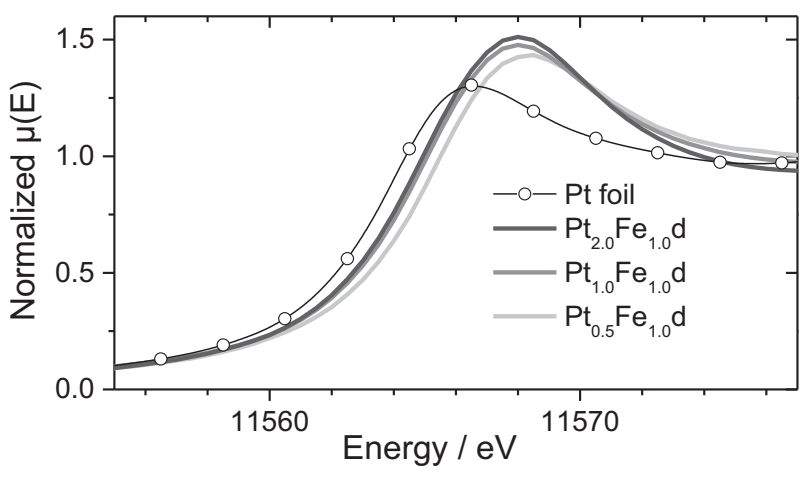

Figure 5. XANES spectra at the $\mathrm{Pt}_{3} \mathrm{~L}_{3}$-edge for the hybrid catalysts with different $\mathrm{Pt}$ contents and, as a reference, the spectrum of a metallic Pt foil.

ORR-activity relative to the activity of $\mathrm{H}_{2} \mathrm{Fe}_{1.0} \mathrm{~d}$. This is also in line with XPS results, showing a high fraction of oxidized Pt (Table S2). A second indication for the lack of, or very low, ORR activity of Pt in the present hybrid catalysts is the 20 times higher kinetic current at $0.9 \mathrm{~V}$ of a benchmark $46 \% \mathrm{Pt} / \mathrm{C}$ catalyst (Figure 7). This 20 times higher activity is observed despite similar platinum loading on the glassy carbon tip for both catalysts (20 and $16 \mu \mathrm{g}_{\mathrm{Pt}} \mathrm{cm}^{-2}$ ). The higher content of carbon in $\mathrm{Pt}_{2.0} \mathrm{Fe}_{1.0}$ d relative to $46 \% \mathrm{Pt} / \mathrm{C}$, however, results in a thicker layer. To account for the possible thickness influence, we physically mixed 5\% Pt/C (ORR-active Pt supported on carbon) with appropriate amounts of $\mathrm{Fe}_{1.0} \mathrm{~d}$ to achieve $2 \mathrm{wt} \% \mathrm{Pt}$ in the mixed material (labelled as $2 \% \mathrm{Pt} /\left(\mathrm{C}+\mathrm{Fe}_{1.0} \mathrm{~d}\right)$ ). Such a mixed layer shows, at a Pt loading of $16 \mu \mathrm{g}_{\mathrm{Pt}} \mathrm{cm}^{-2}$ and with similar thickness (equal
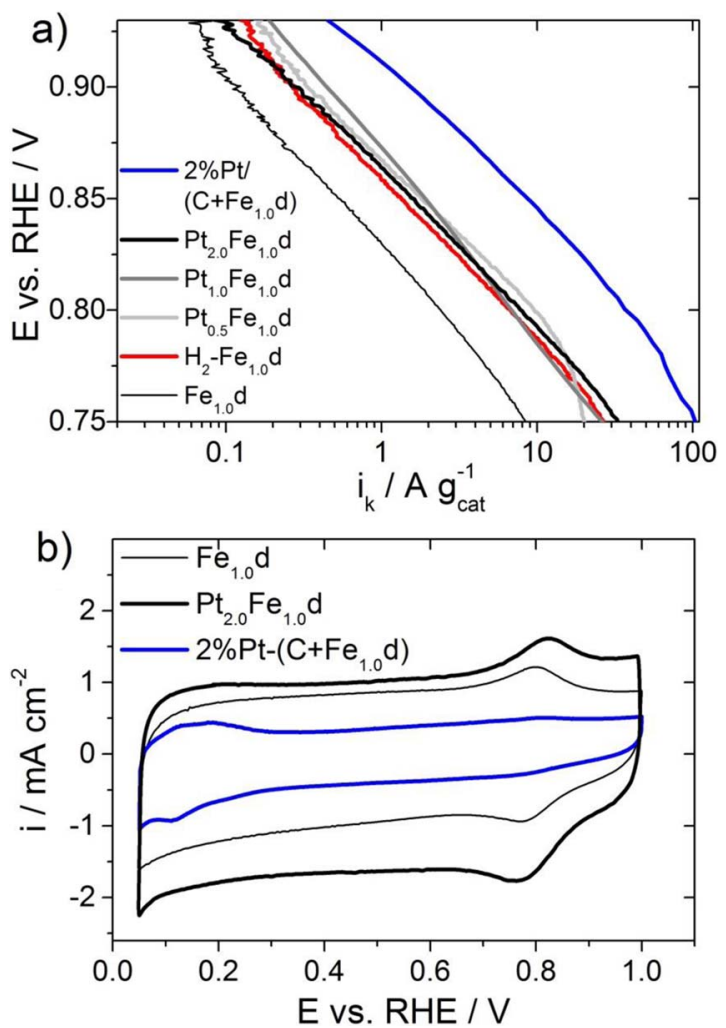

Figure 6. Electrochemical Characterization of the hybrid $\mathrm{Pt} / \mathrm{Fe}-\mathrm{N}-\mathrm{C}$ catalysts and baseline catalysts $\left(\mathrm{Fe}_{1.0} \mathrm{~d}\right.$ and $\mathrm{H}_{2} \mathrm{Fe}_{1.0} \mathrm{~d}$ ) or catalytic layers $\left(2 \% \mathrm{Pt} /\left(\mathrm{C}+\mathrm{Fe}_{1.0} \mathrm{~d}\right)\right)$. a) ORR Tafel plots measured with RDE and normalized to the total catalyst loading $\left(0.8 \mathrm{mg} \cdot \mathrm{cm}^{-2}\right)$; b) cyclic voltammograms at $10 \mathrm{mV} \cdot \mathrm{s}^{-1}$ showing the absence of $\mathrm{H}_{\text {upd }}$-features in $\mathrm{Pt}_{2.0} \mathrm{Fe}_{1.0} \mathrm{~d}$ in contrast to the mixed layer. 


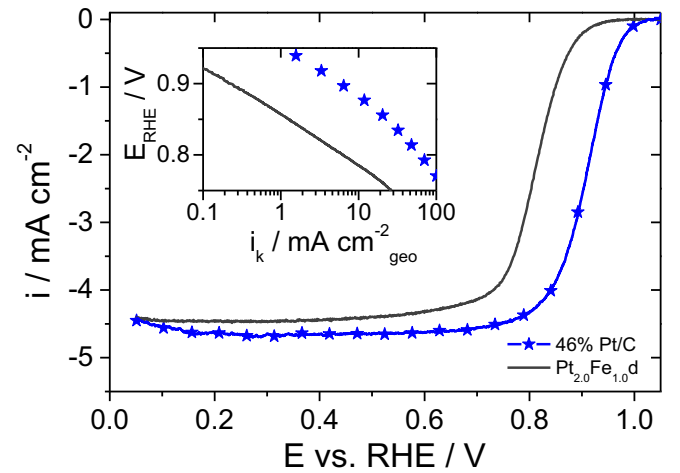

Figure 7. ORR activity of a benchmark $\mathrm{Pt} / \mathrm{C}$ catalyst compared to that of $\mathrm{Pt}_{2.0} \mathrm{Fe}_{1.0}$ d. $\mathrm{N}_{2}$-background corrected ORR polarization curves of $46 \% \mathrm{Pt} / \mathrm{C}$ $\left(20 \mu \mathrm{g}_{\mathrm{Pt}} \mathrm{cm}^{-2}\right)$ in comparison with $\mathrm{Pt}_{2.0} \mathrm{Fe}_{1.0} \mathrm{~d}\left(16 \mu \mathrm{g}_{\mathrm{Pt}} \mathrm{cm}^{-2}\right)$ and the corresponding Tafel plot (inset). Combined with the value of the electrochemical specific surface area from the $\mathrm{H}_{\text {upd }}$ region of the $\mathrm{N}_{2}-\mathrm{CV}$ (not shown), the surface-specific activity for the ORR of $46 \% \mathrm{Pt} / \mathrm{C}$ was $0.38 \mathrm{~mA} \mathrm{~cm}{ }^{-2} \mathrm{Pt}$ at $0.9 \mathrm{~V}_{\mathrm{RHE}}$, agreeing well with literature values.

carbon support loading), a four-fold higher activity than all three present $\mathrm{Pt}_{\mathrm{x}} \mathrm{Fe}_{1.0} \mathrm{~d}$ hybrid materials (Figure 6a, blue curve).

To investigate the surface state of platinum in selected hybrid materials in electrochemical conditions, cyclic voltammetry was utilized to probe the hydrogen underpotential deposition $\left(\mathrm{H}_{\text {upd }}\right)$. In Figure $6 \mathrm{~b}$, the cyclic voltammograms $(\mathrm{CVs})$ of $\mathrm{Fe}_{1.0} \mathrm{~d}, \mathrm{Pt}_{2.0} \mathrm{Fe}_{1.0} \mathrm{~d}$ and the physicallymixed layer $2 \% \mathrm{Pt} /\left(\mathrm{C}+\mathrm{Fe}_{1.0} \mathrm{~d}\right)$ are compared. The mixed layer with ORR-active platinum particles shows $\mathrm{H}_{\text {upd }}$-features, while $\mathrm{Pt}_{2.0} \mathrm{Fe}_{1.0} \mathrm{~d}$ does not, even after extensive cycling. $\mathrm{Pt}_{2.0} \mathrm{Fe}_{1.0} \mathrm{~d}$ only shows a redox peak around $0.8 \mathrm{~V}$ vs. RHE, also visible with $\mathrm{Fe}_{1.0} \mathrm{~d}$, which is assigned to Fe-based active sites. ${ }^{12}$ The complete absence of $\mathrm{H}_{\text {upd }}$-features in the $\mathrm{CV}$ of $\mathrm{Pt}_{2.0} \mathrm{Fe}_{1.0} \mathrm{~d}$ supports the assumption that the platinum surface is either not in contact with the electrolyte or is irreversibly oxidized. As Pt-oxides should be reduced at low potentials, a simple Pt-oxide layer cannot account for the observations. In both hypotheses, the absence of an electrochemically-accessible metallic platinum surface could explain the low or lack of ORR-activity of platinum in the present hybrid materials. In another RDE experiment, the activity of the hybrid materials toward hydrogen-peroxide reduction (HPR) was measured. No significant improvement of the HPR activity was observed for $\mathrm{Pt}_{1.0} \mathrm{Fe}_{1.0} \mathrm{~d}$ with respect to $\mathrm{Fe}_{1.0} \mathrm{~d}$, while $46 \% \mathrm{Pt} / \mathrm{C}$ shows outstanding HPR-activity, as expected (Figure 8). The lack of HPRactivity of platinum in the hybrid materials further supports the above

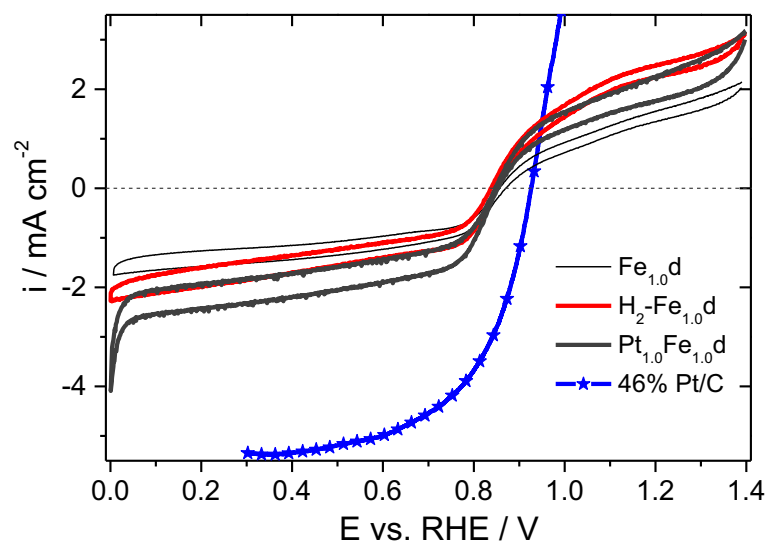

Figure 8. Hydrogen peroxide reduction (HPR) and oxidation in $\mathrm{N}_{2}$-saturated $0.1 \mathrm{M} \mathrm{HClO}_{4}$ with $3 \mathrm{mM} \mathrm{H}_{2} \mathrm{O}_{2}$. The CVs were recorded with $1 \mathrm{mV}^{-\mathrm{s}^{-1}}$ in order to minimize capacitive currents. For $46 \% \mathrm{Pt} / \mathrm{C}$ only, the positive-going scan is shown. The rotation rate is $1600 \mathrm{rpm}$.
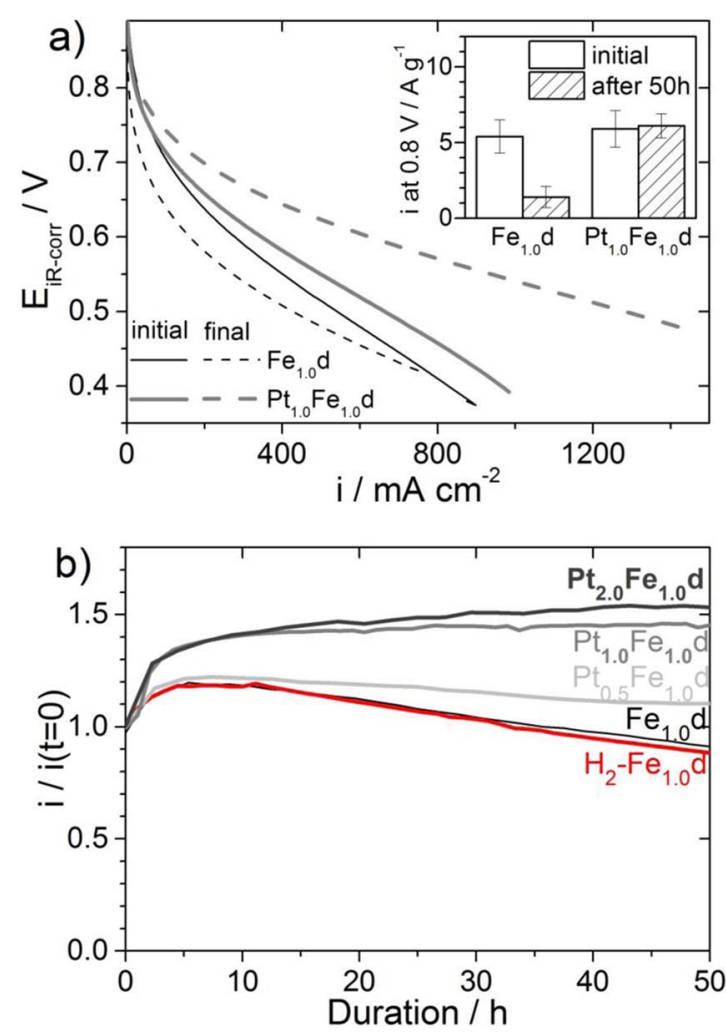

Figure 9. Initial and time-dependent activity and power performance in PEMFC for the baseline Fe-based and the hybrid catalysts. a) iR-corrected fuel cell polarization curves before and after potentiostatic control at $0.5 \mathrm{~V}$ for $50 \mathrm{~h}$, the inset shows the mass activity at $0.8 \mathrm{~V}$, the error bars correspond to the standard deviation for multiple measurements; b) normalized current density $\mathrm{i} / \mathrm{i}(\mathrm{t}=0)$ as a function of time over $50 \mathrm{~h}$ operation at $0.5 \mathrm{~V}$ in PEMFC.

hypotheses, since the onset of HPR on state-of-the-art Pt/C catalysts coincides with the onset for the reduction of reversibly-oxidized platinum. $^{30}$

Characterization in fuel cell.-The present synthesis approach for hybrid $\mathrm{Pt} / \mathrm{Fe}-\mathrm{N}-\mathrm{C}$ materials might, at this stage, appear unsuccessful, platinum being inactive toward ORR and HPR. Astonishingly, we show below that this inactive platinum performs the function that was initially intended, namely stabilizing the Fe-based active sites during steady-state operation in PEMFC. Similar initial activity at $0.8 \mathrm{~V}_{\mathrm{RHE}}$ in PEMFC is observed for all three Pt/Fe-N-C hybrid materials and $\mathrm{Fe}_{1.0} \mathrm{~d}$ (inset of Figure 9a and Figure S2). In order to investigate the stability under operation, we applied a cell voltage of $0.5 \mathrm{~V}$ for $50 \mathrm{~h}$ and recorded the current over time (Figure 9b). $\mathrm{Fe}_{1.0} \mathrm{~d}$ and $\mathrm{H}_{2} \mathrm{Fe}_{1.0} \mathrm{~d}$ behave similarly, showing a slight increase in performance at $0.5 \mathrm{~V}$ over the first $5 \mathrm{~h}$, assigned to improved mass-transport, followed by a linear decrease of the current density with time beyond $5 \mathrm{~h}$. This behavior is well known for Fe-N-C catalysts prepared from ZIF-8 and pyrolyzed in inert atmosphere, even for materials without any inactive Fe-particles, excluding activation by removal of those. ${ }^{31,32}$ $\mathrm{Pt}_{0.5} \mathrm{Fe}_{1.0} \mathrm{~d}$ shows a curbed decay of the current density with time, while the current is fully stable with $\mathrm{Pt}_{1.0} \mathrm{Fe}_{1.0} \mathrm{~d}$. The test was successfully extended to $180 \mathrm{~h}$ for $\mathrm{Pt}_{2.0} \mathrm{Fe}_{1.0} \mathrm{~d}$ (Figure 10). Figure 9a and Figure S2 compare the complete polarization curves from 0.3 to $1.0 \mathrm{~V}$ and mass activities at $0.8 \mathrm{~V}$, measured before and after the $50 \mathrm{~h}$ potentiostatic experiment. For $\mathrm{Pt}_{1.0} \mathrm{Fe}_{1.0} \mathrm{~d}$, the current density is either sustained $(\mathrm{E}>0.8 \mathrm{~V}$, kinetic region) or even increased $(\mathrm{E}<0.8 \mathrm{~V}$, kinetic and mass-transport control). For $\mathrm{Fe}_{1.0} \mathrm{~d}$, in contrast, the current density at any potential above $0.5 \mathrm{~V}$ became lower after $50 \mathrm{~h}$ potential control. In particular, the final activity at $0.8 \mathrm{~V}$ is only $25 \%$ of the initial value (Figure 2c, inset). Since fuel cell efficiency scales with the 


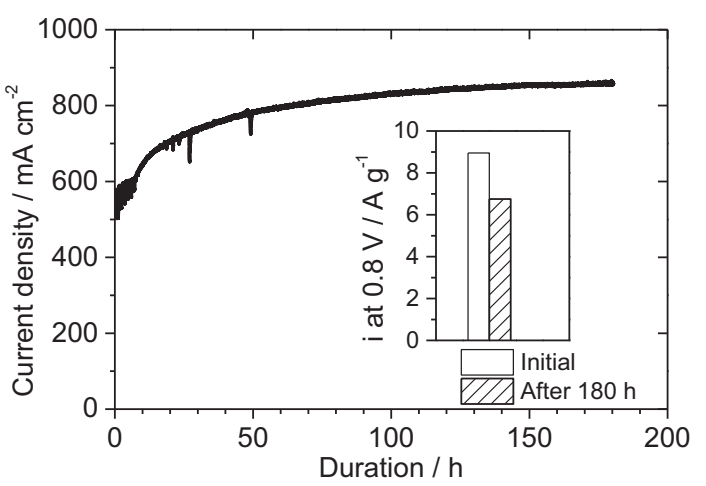

Figure 10. Current density as a function of time during potentiostatic control at $0.5 \mathrm{~V}$ for $180 \mathrm{~h}$ for $\mathrm{Pt}_{2.0} \mathrm{Fe}_{1.0}$ d. The inset shows the initial and final activity at $0.8 \mathrm{~V}$ normalized by total cathode catalyst mass.

ratio $\mathrm{E} / 1.23 \mathrm{~V}$, only stable currents at $\mathrm{E}>0.6 \mathrm{~V}$ are technologically relevant. $^{33}$

The key question, which naturally arises from these results, is related to the origin of the ORR activity at the end of the $50 \mathrm{~h}$ potentiostatic control. Were the Fe-based active sites really stabilized during fuel cell operation, while platinum remained catalytically inactive? Or did the $\mathrm{Fe}$-based active sites degrade as observed with $\mathrm{Fe}_{1.0} \mathrm{~d}$ or $\mathrm{H}_{2} \mathrm{Fe}_{1.0} \mathrm{~d}$, with platinum progressively becoming ORR active, precisely compensating for the loss or deactivation of the Fe-based active sites? A first answer to this question is provided with the behavior of the mixed layer $2 \% \mathrm{Pt} /\left(\mathrm{C}+\mathrm{Fe}_{1.0} \mathrm{~d}\right)$, comprising ORR-active platinum, when subjected to the same protocol (Figure S3). Although its initial activity at $0.8 \mathrm{~V}$ in PEMFC is similar to that of $\mathrm{Pt}_{2.0} \mathrm{Fe}_{1.0} \mathrm{~d}$, the mixedlayer $2 \% \mathrm{Pt} /\left(\mathrm{C}+\mathrm{Fe}_{1.0} \mathrm{~d}\right)$ strongly activates during the $0.5 \mathrm{~V}$ potentiostatic control. This break-in of ORR-active Pt particles in PEMFC during first $10-15 \mathrm{~h}$ of operation is well-known. ${ }^{34}$ The much lower activity of $\mathrm{Pt}_{2.0} \mathrm{Fe}_{1.0} \mathrm{~d}$ vs. $2 \% \mathrm{Pt} /\left(\mathrm{C}+\mathrm{Fe}_{1.0} \mathrm{~d}\right)$ after $50 \mathrm{~h}$ at $0.5 \mathrm{~V}$ thus suggests that the $\mathrm{Pt}$ particles in $\mathrm{Pt}_{2.0} \mathrm{Fe}_{1.0} \mathrm{~d}$ remained inactive during the test.

Investigation of the Fe and Pt species after fuel cell testing.-To gain insight into the nature of the $\mathrm{Fe}$ and $\mathrm{Pt}$ coordination and structures after the $0.5 \mathrm{~V}$ potentiostatic control, several characterization techniques were applied on the $\mathrm{Fe}_{1.0} \mathrm{~d}$ and $\mathrm{Pt}_{1.0} \mathrm{Fe}_{1.0} \mathrm{~d}$ cathodes post mortem and compared to their signal before the PEMFC test.

Possible Fe-coordination changes were investigated with ${ }^{57} \mathrm{Fe}$ Mössbauer spectroscopy. The same cathode was characterized before and after the $0.5 \mathrm{~V}$ potentiostatic control in PEMFC, enabling us qualitatively and quantitatively comparing the signal of each type of Fe-species. Figure 11a reports the Mössbauer spectra for pristine cathodes of $\mathrm{Fe}_{1.0} \mathrm{~d}$ and $\mathrm{Pt}_{1.0} \mathrm{Fe}_{1.0} \mathrm{~d}$ before and after operation in PEMFC at $0.5 \mathrm{~V}$ for $50 \mathrm{~h}$. To accurately fit the spectra recorded after $50 \mathrm{~h}$ PEMFC operation, a third doublet labelled D1* was introduced, having an isomer shift (IS) similar to D1, but a slightly lower quadrupole splitting (QS) value (Table S3). D1* was assigned to a $\mathrm{Fe}^{\mathrm{II}} \mathrm{N}_{4}$ moiety in slightly modified environment relative to D1 (see supporting information text). The column diagram in Figure 11b compares the absolute absorption areas for each spectral component before and after fuel cell operation. This clearly visualizes the significantly reduced total adsorption area for the $\mathrm{Fe}_{1.0} \mathrm{~d}$ cathode after PEMFC operation (gray arrow) but sustained absorption area for $\mathrm{Pt}_{1.0} \mathrm{Fe}_{1.0} \mathrm{~d}$. The absorption area of each spectral component is, assuming the Lamb-Mössbauer factors did not change during PEMFC operation, directly proportional to the Fe content of each component. One can observe that the signals for $\alpha-\mathrm{Fe}$ and $\gamma$-Fe did not change much before and after PEMFC operation (Figure 11b), while the intensity of the signals for D1 and D2 account for the decrease of the total absorption intensity of $\mathrm{Fe}_{1.0} \mathrm{~d}$ after PEMFC operation. For $\mathrm{Fe}_{1.0} \mathrm{~d}$, the signal intensity summed on $\mathrm{D} 1+\mathrm{D} 1^{*}+\mathrm{D} 2$ decreased from 89 to $61 \%$ after $50 \mathrm{~h}$ operation. For $\mathrm{Pt}_{1.0} \mathrm{Fe}_{1.0} \mathrm{~d}$, the signal intensity summed on all three doublets slightly increased from 78 to $83 \%$. While the decrease from 89 to $61 \%$ may at first sight seem not proportionally related to the decrease in ORR activity (divided by ca 4, Figure 9a), one must keep in mind that Mössbauer spectroscopy is a bulk technique while ORR activity is only related to Fe-sites located on the top surface. Thus, if a significant fraction of $\mathrm{FeN}_{4} \mathrm{C}_{\mathrm{y}}$ moieties are not on the surface, the decrease from 89 to $61 \%$ may imply a much higher $\%$ loss than $-28 \%$ of the surface Fe active sites. Alternatively, most of the surface Fe sites may still be present after operation, and in this case the results imply that the Lamb-Mössbauer factors of the surface $\mathrm{Fe}$ sites in $\mathrm{Fe}_{1.0} \mathrm{~d}$ were significantly modified as a result of PEMFC operation. Due to their covalent integration in the carbon matrix, the Lamb-Mössbauer factors of such moieties could be affected by changes in the carbon morphology or chemistry (more oxygen groups) immediately surrounding the $\mathrm{FeN}_{4} \mathrm{C}_{\mathrm{y}}$ active sites. Independently from the difficulty in fully interpreting these spectroscopic results, the Mössbauer study unambiguously reveals that the Fe-based active sites in $\mathrm{Pt}_{1.0} \mathrm{Fe}_{1.0} \mathrm{~d}$ were much less modified after PEMFC operation than those in $\mathrm{Fe}_{1.0} \mathrm{~d}$, also supporting the protective role of ORR-inactive Pt during PEMFC operation.

Figure $11 \mathrm{c}$ shows the $\mathrm{Pt} \mathrm{L}_{3}$-edge XANES spectra of $\mathrm{Pt}_{1.0} \mathrm{Fe}_{1.0} \mathrm{~d}$ before and after $50 \mathrm{~h}$ potentiostatic control at $0.5 \mathrm{~V}$ in PEMFC. The spectra fully overlap, indicating that the oxidation state and coordination of platinum did not change during PEMFC operation. Even more conclusive, electrochemical $\mathrm{CO}$-stripping experiment was performed in PEMFC before and after the $0.5 \mathrm{~V}$ potentiostatic control (Figure 11d). Carbon monoxide strongly adsorbs on metallic Pt, a phenomenon routinely used to determine the surface area of $\mathrm{Pt}$ based electrocatalysts by electrochemical $\mathrm{CO}$ oxidation. No carbon monoxide signal was however detected on $\mathrm{Pt}_{1.0} \mathrm{Fe}_{1.0} \mathrm{~d}$ before and even after PEMFC operation, indicating that platinum initially was and also remained non-metallic, i.e. irreversibly oxidized and therefore ORR-inactive. To verify that a strong CO-signal would be measured at an equally low Pt loading (i.e. $40 \mu \mathrm{g}_{\mathrm{Pt}} \cdot \mathrm{cm}^{-2}$ ) but on a cathode comprising ORR-active $\mathrm{Pt}$ nanoparticles, we performed a reference $\mathrm{CO}$-stripping measurement with a $5 \% \mathrm{Pt} / \mathrm{C}$ catalyst (Figure S4). An intense $\mathrm{CO}$ oxidation peak was observed with onset potential of 0.7 $\mathrm{V}_{\mathrm{RHE}}$ as expected. These results unambiguously demonstrate that the $\mathrm{Pt}$ nanoparticles in the hybrid catalyst $\mathrm{Pt}_{1.0} \mathrm{Fe}_{1.0} \mathrm{~d}$ were not active initially and did not activate within the $50 \mathrm{~h}$ potentiostatic period. Thus, both the initial and final ORR activities in $\mathrm{Pt}_{1.0} \mathrm{Fe}_{1.0} \mathrm{~d}$ can be assigned to Fe-based active sites.

\section{Conclusions}

Extensive initial and post experiment characterization of the catalysts and PEMFC electrodes before and after fuel cell operation at $0.5 \mathrm{~V}$ for $50 \mathrm{~h}$ imply that the platinum surface is initially irreversibly oxidized, although not necessary as an oxide, in the hybrid Pt/Fe-N-C catalysts of the present study. The irreversibly-oxidized Pt surface is catalytically inactive toward ORR and HPR. It however stabilizes the Fe-based active sites during operation in PEMFC at $0.5 \mathrm{~V}$, with fully sustained activity at $0.8 \mathrm{~V}$ after $180 \mathrm{~h}$, for Pt content $\geq 1 \mathrm{wt} \%$.

Currently, the detailed structure of the present Pt-particles and the mechanism through which they protect the Fe-based active sites are still unclear. Resolving these questions will require further investigation. Since $\mathrm{H}_{2} \mathrm{O}_{2}$ or reactive oxygen species (ROS) generated on $\mathrm{Fe}-$ sites likely play a critical role in the degradation mechanism of $\mathrm{Fe}-\mathrm{N}-\mathrm{C}$ cathodes during operation, we postulate that the oxidized Pt-surface acts as peroxide or ROS scavenger. Currently, we can exclude that $\mathrm{H}_{2} \mathrm{O}_{2}$ itself interacts with the oxidized Pt-surface, as we detected no enhanced electroreduction of $\mathrm{H}_{2} \mathrm{O}_{2}$. However, an oxidized Pt surface might chemically scavenge peroxide or ROS. Although the overall ORR activity of the present hybrid $\mathrm{Pt} / \mathrm{Fe}-\mathrm{N}-\mathrm{C}$ catalysts normalized to the Pt mass is not yet ground-breaking, the observation that $\mathrm{Fe}$ based active sites can be independently stabilized during operation by a second compound introduces a completely new approach to solving the stability issue of Fe-based active centers. This greatly simplifies the otherwise complex goal of forming operationally-stable and at the 

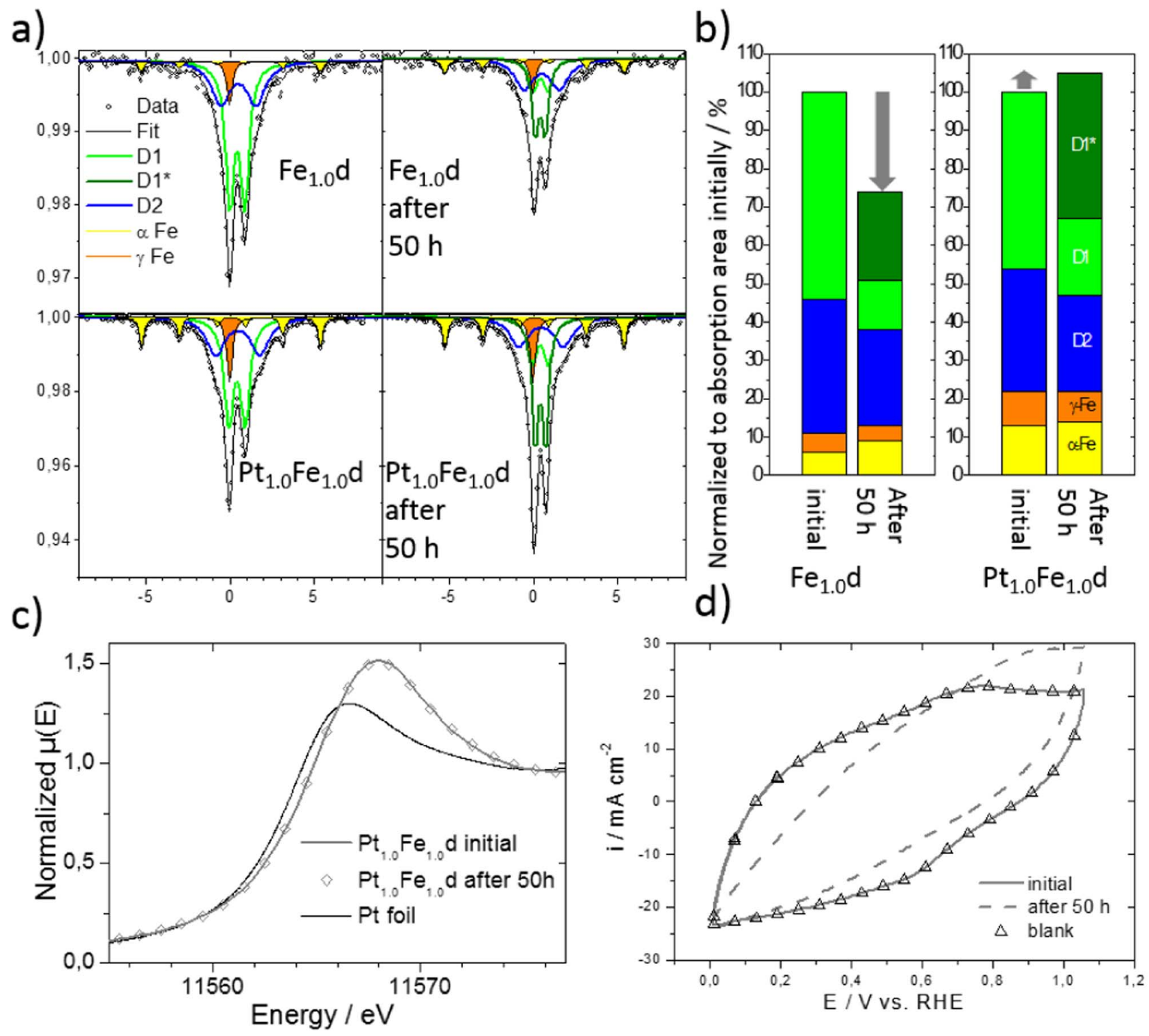

Figure 11. spectroscopic and CO-stripping characterization of Fe and Pt before and after the $0.5 \mathrm{~V}-50 \mathrm{~h}$ potentiostatic control in PEMFC. For each potentiostatic experiment, the same cathode was characterized before and after PEMFC operation. a) ${ }^{57} \mathrm{Fe}$ Mössbauer spectra of cathodes showing Fe speciation in Fe ${ }_{1.0} \mathrm{~d}$ or $\mathrm{Pt}_{1.0} \mathrm{Fe}_{1.0}$ d. b) Absorption area below each spectral component as derived from the fittings seen in a). For each cathode, the total area was normalized to the absorption area of the initial spectrum. c) XANES spectra at the $\mathrm{Pt}_{2}$ edge and comparison to a reference Pt foil. d) $\mathrm{CO}$-stripping of $\mathrm{Pt}_{1.0} \mathrm{Fe}_{1.0} \mathrm{~d}$. For d), the blank measurement corresponds to the scan immediately following the CO-stripping scan, on the electrode before PEMFC operation.

same time active non-PGM-based active sites. Instead, the optimization of activity and stability are effectively decoupled in the present hybrid catalysts. Ultimately, the Pt-compound might be replaced by a non-precious species that can perform the same stabilization task, to achieve active and stable non-precious-metal cathodes for PEMFC.

\section{Acknowledgments}

The authors acknowledge Marc DuPont (UM) for assistance with the fuel cell measurements. We also thank Prof. Hubert Gasteiger (TUM) for assistance with the PEMFC-environment CO-stripping measurements and as supervisor of J.N.S. The project was partially funded by the European Union within the CATAPULT project (grant agreement no. 325268) and the Ministry of Foreign Affairs of France represented by Campus France.

\section{ORCID}

Anna K. Mechler (D) https://orcid.org/0000-0002-0491-514X
Jan N. Schwämmlein (1D https://orcid.org/0000-0001-8902-4508 Frédéric Jaouen (D) https://orcid.org/0000-0001-9836-3261

\section{References}

1. F. Jaouen, in Z. Chen, J.-P. Dodelet, and J. Zhang Dodelet, editors, Non-Noble Metal Fuel Cell Catalysts, 29-118. Wiley-VCH Verlag GmbH \& Co. KGaA, Weinheim, Germany (2014)

2. G. Wu, K. L. More, C. M. Johnston, and P. Zelenay, Science, 332, 443 (2011).

3. D. Zhao, J.-L. Shui, L. R. Grabstanowicz, C. Chen, S. M. Commet, T. Xu, J. Lu, and D.-J. Liu, Adv. Mater., 26, 1093 (2014).

4. G. Zhang, R. Chenitz, M. Lefèvre, S. Sun, and J.-P. Dodelet, Nano Energy, 29, 111 (2016).

5. M. Ferrandon, X. Wang, A. J. Kropf, D. J. Myers, G. Wu, C. M. Johnston, and P. Zelenay, Electrochim. Acta, 110, 282 (2013).

6. C. H. Choi, C. Baldizzone, J.-P. Grote, A. K. Schuppert, F. Jaouen, and K. J. J. Mayrhofer, Angewandte Chemie International Edition, 54, 12753 (2015).

7. G. Wu, K. Artyushkova, M. Ferrandon, A. J. Kropf, D. Myers, and P. Zelenay, ECS Transactions, 25, 1299 (2009).

8. F. Charreteur, F. Jaouen, and J.-P. Dodelet, Electrochim. Acta, 54, 6622 (2009). 
9. S. Baranton, C. Coutanceau, C. Roux, F. Hahn, and J.-M. Leger, Journal of Electroanalytical Chemistry, 577, 223 (2005).

10. V. Goellner, V. Armel, A. Zitolo, E. Fonda, and F. Jaouen, J. Electrochem. Soc., 162 H403 (2015)

11. F. Jaouen and J.-P. Dodelet, J. Phys. Chem. C, 113, 15422 (2009),

12. U. Tylus, Q. Jia, K. Strickland, N. Ramaswamy, A. Serov, P. Atanassov, and S. Mukerjee, J. Phys. Chem. C, 118, 8999 (2014).

13. A. Bouwkamp-Wijnoltz, W. Visscher, and J. van Veen, Electrochim. Acta, 43, 3141 (1998).

14. Y. Qin, L. Chao, J. J. He, Y. Liu, F. Chu, J. Cao, Y. Kong, and Y. Tao, J. Power Sources, 335, 31 (2016).

15. S.-M. Hwang, Y. Choi, M. G. Kim, Y.-J. Sohn, J. Y. Cheon, S. H. Joo, S.-D. Yim K. A. Kuttiyiel, K. Sasaki, R. R. Adzic, and G.-G. Park, J. Mater. Chem. A, 4, 5869 (2016).

16. T. Palaniselvam, A. Irshad, B. Unni, and S. Kurungot, J. Phys. Chem. C, 116, 14754 (2012)

17. B. N. Popov, X. Li, G. Liu, P. Ganesan, H. Kim, B. Roh, and I. Hwang, ECS Transactions, 41, 955 (2011).

18. G. Wu, C. Dai, D. Wang, D. Li, and N. Li, J. Mater. Chem., 20, 3059 (2010)

19. M. T. Sougrati, V. Goellner, A. K. Schuppert, L. Stievano, and F. Jaouen, Catal. Today, 262, 110 (2016).

20. U. I. Kramm, J. Herranz, N. Larouche, T. M. Arruda, M. Lefèvre, F. Jaouen, P. Bogdanoff, S. Fiechter, I. Abs-Wurmbach, S. Mukerjee, and J.-P. Dodelet, Phys. Chem. Chem. Phys., 14, 11673 (2012).
21. U. I. Kramm, I. Herrmann-Geppert, J. Behrends, K. Lips, S. Fiechter, and P. Bogdanoff, Journal of the American Chemical Society, 138, 635 (2016).

22. J. Xu, G. Fu, Y. Tang, Y. Zhou, Y. Chen, and T. Lu, J. Mater. Chem., 22, 13585 (2012).

23. V. K. Kaushik, Zeitschrift für Physikalische Chemie, 173, 105 (1991).

24. J. R. Croy, S. Mostafa, H. Heinrich, and B. R. Cuenya, Catal. Lett., 131, 21 (2009).

25. M. Nesselberger, S. Ashton, J. C. Meier, I. Katsounaros, K. J. J. Mayrhofer, and M. Arenz, Journal of the American Chemical Society, 133, 17428 (2011)

26. H. Yoshida, S. Nonoyama, and Y. Y. T. Hattori, Phys. Scr, 813 (2005).

27. E. Gregoryanz, C. Sanloup, M. Somayazulu, J. Badro, G. Fiquet, H.-K. Mao, and R. J. Hemley, Nature Materials, 3, 294 (2004)

28. J. C. Crowhurst, Science, 311, 1275 (2006).

29. V. Goellner, C. Baldizzone, A. K. Schuppert, M. T. Sougrati, K. J. Mayrhofer, and F. Jaouen, Phys. Chem. Chem. Phys., 16, 18454 (2014).

30. I. Katsounaros, W. B. Schneider, J. C. Meier, U. Benedikt, P. U. Biedermann, A. A. Auer, and K. J. J. Mayrhofer, Phys. Chem. Chem. Phys., 14, 7384 (2012).

31. E. Proietti, F. Jaouen, M. Lefèvre, N. Larouche, J. Tian, J. Herranz, and J.-P. Dodelet, Nat. Commun., 2, 416 (2011)

32. C. H. Choi, C. Baldizzone, G. Polymeros, E. Pizzutilo, O. Kasian, A. K. Schuppert, N. Ranjbar Sahraie, M.-T. Sougrati, K. J. J. Mayrhofer, and F. Jaouen, ACS Catal., 6, 3136 (2016).

33. H. A. Gasteiger and J. Garche, In G. Ertl, H. Knözinger, F. Schüth, and J. Weitkamp, editors, Handbook of Heterogeneous Catalysis, Wiley-VCH, Weinheim, Germany (2008).

34. X.-Z. Yuan, S. Zhang, J. C. Sun, and H. Wang, J. Power Sources, 196, 9097 (2011). 